\title{
Homo Virtualis
}

Vol 2, No 1 (2019)

Blockchain and disruptive technologies in social sciences: Interdisciplinary perspectives

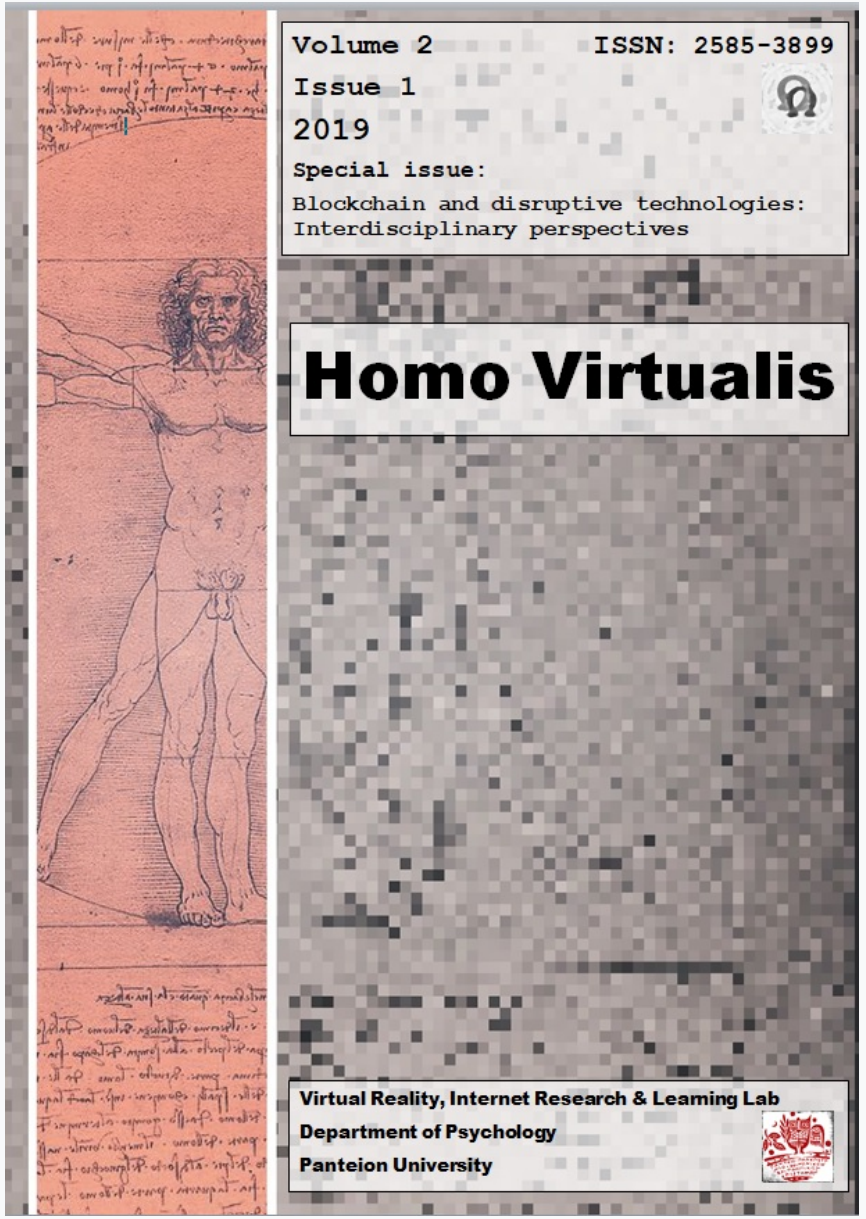

The urban question in the context of the "double world"

Stella Kyvelou

doi: $10.12681 /$ homvir.21164

Copyright @ 2019, Stella Kyvelou

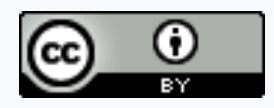

This work is licensed under a Creative Commons Attribution 4.0.

\section{To cite this article:}

Kyvelou, S. (2019). The urban question in the context of the "double world". Homo Virtualis, 2(1), 108-112.

https://doi.org/10.12681/homvir.21164 


\title{
The urban question in the context of the "double world"
}

\author{
Stella Kyvelou ${ }^{1}$
}

\begin{abstract}
Once the principle of the inseparability of the material world and cyber territory has been admitted, the question put to the urban planner is being transformed. The transition from the representation of two separate worlds - the physical on the one hand and the digital on the other - to a representation of a "double world" in the sense of the indivisible inter-connection of the physical and the digital, leads to a change of paradigm in abstraction and representation. By accepting the principle of considering the material world and the cyber territory (and not cyberspace) as an indivisible whole, we come up to realize that the urban question changes. If, in the past, our thoughts and studies were aimed at seeking a common world that we should discover and maintain, the modern world is not presumed to belong exclusively in the material reality. The planner's work, therefore, should certainly take into account this interconnection, the discontinuous, fragmentary involvement, of matter and information. However, this phenomenon is not new since the symbolic dimension of cities, architecture and space in general has always closely interwoven representation and the real world. The difference is that there was then a connection with a particular territory or a national identity. Today, this ancient territorial reference is weakening, although there are signs of reversion to it. Based on these observations, the paper will discuss the evolution of the urban question under the assumption of the indivisible "double world" and the augmented territories.
\end{abstract}

Keywords: cyber territory, physical world, digital world, augmented territories, urban question

\section{Introduction}

The transition from the representation of two separate worlds - the physical on the one hand and the digital on the other - to a representation of a "double world" in the sense of the indivisible interconnection of the physical and the digital, leads to a change of paradigm in abstraction and representation. In the augmented city, "virtual" and physical spaces are no longer two distinct dimensions but parts of a whole, a spatial continuum (Aurigi \& De Cindio, 2016).

\footnotetext{
${ }^{1}$ Associate Professor, Dept. of Economic and Regional Development, Panteion University of Social and Political Sciences, E-mail: kyvelou@panteion.gr
} 
By accepting the principle of indivisibility of the material world and the cyber territory, in the sense of a cyber/digital territory and not cyberspace in general, the urban question changes. We should remember that "territory" is not just part of a nation or an administrative region, but a form of organisation and coordination that is geographically recorded and socially structured. A "territory" is a geographical entity that humans take ownership of and in which they define their identity. It is a space in which they have chosen to live and share common values and common habits and for which they jointly formulate a development plan.

It is therefore understandable that if our ideas and studies until recently aimed at searching for a common world that we would have to discover and maintain, the modern common world is not presumed to belong exclusively in material reality. Consequently, the objective of the urban planner or any other spatial planner will have to take into account this interconnection; the discontinuous, fragmentary involvement, one could say, of matter and information. However, this phenomenon is not new since the symbolic dimension of cities, architecture and space in general has always closely interwoven representation and the real world. The difference is that there was then a connection with a particular territory (country) or a national identity. Today, this forced territorial reference is weakening, although there are signs of reversion to it. Based on these observations, the paper will discuss the evolution of the urban question under the assumption of the indivisible "double world".

\section{The glamour of high-speed connection}

The state is often called upon to respond to disadvantaged territories needing support because they are inert and have been drawn into a spiral of underdevelopment. Is it possible that, for the inhabitants of these areas, a high-speed connection to cyberspace, non-territorial by nature, could provide sufficient energy in order that these areas could recover? It would appear that people who, for various reasons, no longer have the means to take ownership of their physical "territory", are also not in a favorable position to be able to realize this type of beneficial transmutation; in other words, to participate in the "reterritorialisation" (Deleuze \& Guattari, 1991) that takes place in the cyberspace and could serve as a catalyst for a new beginning.

It also appears that here in cyberspace, too, only the wealthy that have access to new technologies, amongst other things, stand to benefit. The a-spatial (non-geographical) nature of "cyber-territory" allows it to expand points of entry into cyberspace at will, provided the State or private enterprises are investing: but what is the guarantee that these points will act more as a tool to develop a specific "territory" than as a means of subjugating it to another, more powerful and more organised "territory" (physical, digital or both physical and digital)? For example, aren't countries and "territories" in general which are endowed with high-speed and low-cost access to the internet or to mobile telephony in a more competitive position, compared to those which impose high taxes and have only low-speed services? 


\section{Planning of augmented territories}

The description of the modern world as comprising two separate worlds, the physical and the digital (cyber), divided by a border that we can cross depending on our activities, appears to lag behind in comparison to a double world where we equally use the best physical potential of the digital (cyber) consciously chosen only on the basis of greater economic efficiency. It is clear that this new type of world radically changes the concepts and tools used by spatial planners. We could also, here, mostly refer to the concept of territorial cohesion (Faludi, 2005; Kyvelou, 2010).

Space in the double world simultaneously contains both traditional and real time. The main concepts highlighted here are uncertainty and mobility, replacing deterministic and static urban solutions. The latter can quickly change, on condition that urban planning regulations help to break through older limitations and allow the acceptance of new opportunities.

Thus, a first recommendation for those who design space would be to accompany the installation of "high speeds" with a new reading of the physical space. This new knowledge would lead to an urban program that would have the potential for private actors to intervene, much more than in a predetermined urban plan.

\section{Living in the modern world}

Whether the "territories" in the classical sense of the term, both local and global, have literally been "fluidized" within the "global city" or "megacity", the effects of this new reality are not yet visible. The "global city" can lead to increased entropy, to homogeneity, to the levelling of differences with a mirroring between a physical world comprising museumified historical cities, impoverished suburbs and enclosed "wealthy areas" and a digital world monopolized by some major companies which naturally favor consumers over citizens.

This global city, however, can generate new dynamics and play a part in revealing new identities arising from experiencing multiple places, simultaneously physical and digital. This multi-dimensional global city could also create new methods of "coexistence", both in close proximity and remotely - we already experience this through social media. These methods could potentially allow for new creative approaches that can ascribe new possibilities to "territories" that seem to be in decline or at a deadlock.

So a second finding (and at the same time recommendation) could be that there is no sense in developing augmented "territories" if we cannot also rely on human capital to jump-start development processes.

\section{Humans at the centre of the architecture of augmented "territories"}

At first glance, we can imagine that augmenting a territory has more to do with implanting, or grafting, new digital tools onto a physical substratum, than in-depth questioning and redesigning its structures. This minimalist way of looking at things might possibly be the best way to transform the concept of augmented "territories" into a type of "gadget" to avoid undertaking a deep paradigm change. The transformation of a collective territory in 
crisis into an "augmented territory" means, first of all, a change in attitude: the lack of trust will have to be overcome and a social and urban ecosystem will have to be created that is favourable to the appearance of new types of creativity.

This plan for changing attitudes, for example, could be expressed and expanded through the architecture of territory with new types of public spaces that will host collective activities, that will mix work activities with leisure-time activities, and which will be intended to foster productive exchanges and crosses of physical with digital. It is also possible that spaces and buildings will emerge, intended for experimentation even for new ways of life, as a result of the transformation of the landscape's identity in order to adapt it to a new era.

And naturally, the physical transformation of a territory into a "double" territory can only acquire meaning if civil society and public authorities (including local administration) are involved in order to invent new, creative and active ways for owning the potential of this new world.

\section{Discussion-Conclusion}

In concluding my attempt at "touring" and/or "navigating" today's "double world", I would say that what characterizes it, on one hand, is that the physical "territory" refers to inertness, to the long term, in other words a territory that tends to evolve through historic events, crises, wars and other social transformations.

On the other hand, another territory has begun to emerge, which, in contrast to the classical world, is a world of instability and almost zero inertness. What is new and may ultimately be exciting is this continual transition from one world to the other, from the inert world to the real-time world and the reverse.

Being bold enough to extend this new reality, I believe that this transition will lead to a new philosophical view of the world... Gilles Deleuze and Felix Guattari refer to "becoming" in terms of "territorialisation", "de-territorialisation" and "re-territorialisation". These are precisely the terms that correspond to the dissolution of the closure (entrenchment) of territories and their opening into another space, e.g. the ocean and sea space (Kyvelou, 2016) - why not into digital space as well - and to their reconstitution in light of new knowledge and the nature of their opening itself.

They argue, for example, that philosophy was born in Greece because the country is a peninsula, from which the sea is easily accessible. This allows for "de-territorialisation" into the sea. Its organisation in democratic cities allowed for this de-territorialisation and the reterritorialisation that followed, in a "horizontal movement" (as opposed to the Eastern countries where the re-territorialisation was vertical to the body of the emperor identified with the country and the land.)

This horizontal movement allowed the emergence of philosophy in Greece as the ability to synthesize knowledge, socially, economically and politically. "... for there to be Thought and a fortiori creation, there must be an 'out' and an encounter with the strange ..." (Deleuze \& Guattari, 1991). 
Is this "out" and encounter with the "strange" not the unexplored "cyberspace" of today or the augmented reality and a meeting between the two worlds - the world of inertness and the world of real time?

\section{References}

Aurigi, A. \& Cindio de, F. (2008). Augmented urban spaces: articulating the physical and electronic city. Aldershot, Hampshire, England; Burlington, VT: Ashgate.

Deleuze, G. \& Guattari, G. (1991). Qu'est-ce que la philosophie? Paris: Editions de Minuit.

Duarte, F. \& Firmino, R.J. (2009). Infiltrated city, augmented space: information and communication technologies, and representations of contemporary spatialities. The Journal of Architecture 14 (5), 545-565.

Faludi, A. (2005), Territorial Cohesion (Special Issue). Town Planning Review 76 (1), 1-118.

Kyvelou, S. (2010). From spatial planning to spatial management: the concept of strategic spatial planning and territorial cohesion in Europe. Athens: Kritiki Publications.

Kyvelou, S. (ed.) (2016). Maritime dimension of territorial cohesion, maritime spatial planning, sustainable blue growth (Maritime Spatial Issues). Athens: Kritiki Publications.

\section{Notes on contributor}

Stella Kyvelou is Associate Professor and Deputy Head at the Department of Economic and Regional Development of Panteion University of Social and Political Sciences. She holds a diploma of Architect-Engineer of the National Technical University of Athens and a DEA and PhD in Spatial Planning, Regional \& Urban Planning of the University Paris I-Panthéon-Sorbonne. Her research activities include sustainable urban development and European territorial development and cohesion; she was Director of the ESPON2013 National Contact Point (2007-2014). Author of books and articles, columnist in electronic media and keynote speaker in numerous conferences, Stella was awarded by the French government as "Chevalier à l'ordre de Palmes Académiques", in 2011. She is also Special Adviser to the Minister of Maritime Affairs and Insular Policy on insular policies and maritime spatial planning. 